\title{
ADDRESS FORM AS A REFLECTION OF ETHNO-CULTURAL STYLE OF COMMUNICATION (based on British and Canadian English)
}

\author{
Yulia B. Yuryeva \\ Peoples' Friendship University of Russia (RUDN University) \\ 6, Miklukho-Maklaya Str., Moscow, Russia, 117198
}

\begin{abstract}
Culture and the process of communication are interrelated, since culture not only indicates between which members of the society a communication act is possible, but also helps to decode correctly the meaning of the message that was encoded, and also according to what conditions the message would be correctly interpreted by the interlocutor. The historically established ethno-cultural style of communication (T. Larina) reflects the communicative peculiarities of people's behavior when choosing verbal and non-verbal means in the process of communication.

The article is devoted to sociocultural features that influence the choice of language means for expressing an initial speech formula. The aim of our research is to examine address forms in the boundaries of one language but in two different countries (Canada, Great Britain) with their historical and cultural background. We draw on Cultural Dimensions of G. Hofstede (1991), the Theory of Politeness (Brown \& Levinson 1987, Leech 2014), the background of Intercultural Pragmatics (A. Wierzbicka 2003, I. Kecskes 2014), Speech Accommodation Theory (Giles 1977) and etc. The article presents the results of the study on the usage of address forms among the representatives of British English (BrE) and Canadian English (CanE) in order to identify similarities and differences and to explain the results according to cultural characteristics.
\end{abstract}

Key words: initial speech formula, address forms, Canadian English, British English, intercultural communication

\section{INTRODUCTION}

Nowadays our modern world is developing along the way of cooperation in all spheres of human life. Each of us, regardless of belonging to one or another linguocultural community, is in a situation where it is necessary to address the interlocutor in order to start a communicative act. The process of communication and culture are interrelated and have a mutual influence on each other. Experience, perception and culture have a great impact on the style of communication. Culture provides its members with an implicit knowledge of how to behave and how to interpret the behavior of the representatives of other cultures in different situations. Any communicative act begins with an initial speech formula, which can be expressed by different means and may include nominative address forms. Since childhood, the representatives of different cultures learn that address forms depend greatly on various factors: on social and gender characteristics of the addressee (age and gender), relationships between the interlocutors, the communication situation as well.

As the process of communication is a complex multidimensional process, there are two types of interactions between the interlocutors: 1. aimed at cooperation (coopera- 
tion); 2. aimed at creating competition (conflict). For the successful communicative act the speaker needs to choose proper address forms taking into account his / her intentions and expectations of the addressee. According to the address forms which a speaker may use while addressing the interlocutor s/he define their relationships. As Fitch distinguishes, the relationships may be close / distant, personal / professional, peers / rank-differentiated, etc. [7].

The issue of intercultural communication is much more complicated as the representatives of each culture share the rules which are normally shared by the representatives of their own cultural community. During our research we draw on the cultural dimensions of G. Hofstede (1991), the theory of politeness (Brown \& Levinson 1987, Leech 2014), the background of intercultural pragmatics (A. Wierzbicka 2003, I. Kecskes 2014), Speech Accommodation Theory (Giles 1977) and etc. [3-6; 10].

English is a global language and the term "English as an International Language" (EIL) corresponds to British English (BrE), Canadian English (CanE), American English (AmE), Australian English (AusE). The aim of our research is to examine address forms in the boundaries of one language but in two different countries (Canada, Great Britain) with their historical and cultural background.

This paper investigates the social and cultural features that govern the use of address forms in BrE and CanE while addressing a stranger in everyday situations focusing mainly on similarities and differences. The data for analysis was collected through questionnaires, interviews and ethnographical observations. The given situation was chosen in order to determine the cultural impact on the usage of address forms according to symmetrical and asymmetrical relationships among the interlocutors referring to the age.

\section{DATA AND METHODOLOGY}

The data for analysis was collected through questionnaires, interviews and ethnographical observations. The aim of our research was to examine address forms in the boundaries of one language but in two different countries (Canada, Great Britain) with their cultural and historical background. During our research we collected and tried to examine the address forms which were normally used while addressing a stranger in everyday situations. The given situation was chosen in order to determine the cultural impact on the usage of address forms in accordance with symmetrical and asymmetrical relationship among the interlocutors referring to the age.

In order to explain the differences in the usage of address forms we have based our contrastive analyses on the cultural dimensions of G. Hofstede (1991), the theory of politeness (Brown \& Levinson 1987, Leech 2014), Speech Accommodation Theory (Giles 1977) and etc.

The questionnaire was filled in by fifty Canadian and fifty British informants (mostly middle aged informants with high education). This article is focused on the results which reveal the essential similarities and differences in the usage of address forms among the representatives of two different cultures in accordance to age difference. It's important to mention that the collected data needs more detailed analyses on the assumption of gender and social differences. 


\section{THE IMPACT OF CULTURE ON COMMUNICATIVE BEHAVIOR}

Culture and the process of communication are inseparable, as culture not only indicates between which members of the society a communication process is possible, but also helps to understand the correct meaning of the message that was encoded, and also under what conditions the message will be correctly interpreted by the interlocutor.

The process of communication is a way of people's activity, during which interlocutors may encounter various problems: violation of personal space, inappropriate style and way of communication. The communication process includes sending both: verbal messages (words, messages) and non-verbal messages (distance between interlocutors, gestures and etc.).

As the process of communication is a complex multidimensional process, there are two types of interactions between the interlocutors: 1. aimed at cooperation (cooperation) and 2. aimed at creating competition (conflict). That is why communicative behavior can be divided into normative and non-normative. The first one is observed by the overwhelming majority of the representatives of the community and is aimed at a successful communication process. The second one is connected with the violation of generally accepted norms and rules of behavior in the society by the representatives of a single group.

During the process of communication, the participants use not only universal strategies adopted in the world, but also individual and ethnocultural ones. An incorrect perception of communicative behavior by the representatives of a single culture can lead to misunderstanding, and as a result may lead to an interpersonal or an inter-ethnic conflict situation.

As for communicative behavior, it can be considered in three different aspects: individual, situational, and cultural. Intercultural norms reflect the generally accepted rules of polite communication in everyday situations (address, acquaintance, greeting, apology and etc.). However, the general cultural norms of behavior are nationally specific. While greetings a smile is obligatory for Americans and Canadians, unlike for British people.

In the intercultural aspect, culture predetermines the behavior of its representatives and allows us to identify and understand the national and cultural characteristics of the representatives of different cultures.

According to G. Hofstede there are 4 dimensions for the classification of cultures: individualism - collectivism; power distance; uncertainty avoidance; femininity masculinity.

In accordance with the classification of G. Hofstede UK (89) and Canada (80) top the list of the most individualistic cultures. For people in these countries, their personal interest is of great importance. But they don't always pay much attention to interests of the family, group or team. The representatives of this type of culture value independence, equality and respect human rights. The representatives of these countries make all decisions only in their own interests, and not in the interests of the collective, team or group. Moreover, this society is focused on respecting the rights of each member of society and the value of human life. 
The second dimension for measuring cultures - Power Distance is associated with an equal / unequal distribution of power within an institution or society. Based on the classification of G. Hofstede, UK (35) and Canada (39) are countries with a small Power Distance. Representatives of culture with a small power distance value equal rights, equal distribution of power. According to these dimensions, status and social distance are interrelated: a lower power index is characteristic for individualistic countries, and a higher power distance is characteristic for collectivistic countries.

Uncertainty avoidance is a degree of discomfort or level of anxiety that representatives of different cultures may experience in unclear, uncertain situations. As far as people are not afraid of awkward or conflict situations or, on the contrary, they try to avoid them. According to the classification of G. Hofstede, Canada (48) and the United Kingdom (35) belong to cultures with a low degree of uncertainty avoidance. These cultures are characterized by uncertainty, dynamism, high mobility, challenges and risks, high tolerance for unknown situations, new ideas.

The fourth dimension of culture - masculinity / femininity is associated with its organization, which is characteristic for culture. In the masculine culture, the social roles of men and women are clearly determined. The man is focused on completing tasks and achieving success. A woman, in turn, is feminine, tender. Unlike masculine cultures, in a feminist culture, the social roles of men and women are not clearly defined and may overlap. In such cultures, much attention is paid to education, spiritual values. In accordance with this parameter, England (66) and Canada (52) occupy a middle place [3].

An American anthropologist E. Hall has divided cultures into:

— high / low context;

- monochronic / polychronic;

- the difference in proxemics.

Based on this theory, high context cultures are characterized by a large number of non-linguistic context (appearance, hierarchy), which is already laid in the minds of representatives of this culture for a complete and correct interpretation of the message. Low context cultures express a large part of verbal information. The representatives of these cultures openly express their desires and intentions, their messages do not contain hidden meaning or understatement. This type of cultures includes Canada and England.

Monochronic / polychronic cultures differ in their attitude to time. In monochronic cultures, which include Canada and the United Kingdom, only one kind of activity is possible in one period of time, all actions occur sequentially, one by one. In polychronic cultures, several actions may be done simultaneously by the representatives of these cultures, during one period of time.

The third parameter of culture is the difference in proxemics (the way a person identifies interpersonal space) in each culture is different and, depending on the culturally-determined features, can be incorrectly interpreted by the representatives of another culture. On the basis of 4 interpersonal spaces, cultures can be divided into 2 types: personal / public space. In cultures with the predominant role of personal space, personal distance, autonomy of personality are valued, all meetings are discussed in advance, as they can be regarded as an invasion of personal space (England, Canada) [15]. 
Both British and Canadian cultures are characterized by equality and distance in communication. According to cultural characteristics the interlocutors normally use informal norms while addressing strangers in everyday communication, so they seldom have difficulties while interacting with people.

Politeness is connected with the basic principles of sociocultural organization and interpersonal relationships within social groups and should be viewed in the context of Social distance and Power distance, which are considered the main dimensions of cultures [14. C. 534].

Address forms as the initial speech formula depict ethnocultural differences while a speech act. While addressing people, people evoke personal identities, create and define relationships such as close / distant, personal / professional, peers / rank-differentiated, etc. [7]. As British people and Canadians are the representatives of individualistic cultures they value mainly equality and try not to show differences in social status, as well as they don't reveal the asymmetry in age and gender.

\section{ADDRESS FORMS IN BRITISH ENGLISH}

According to the research, the representatives of British English are limited in the variety of address forms in a given situation (while addressing a stranger). Normally the speaker doesn't use address forms. The speakers prefer to address the stranger with the help of the "attention getter" — Excuse me, without any address forms in order to attract attention of the interlocutor. Informants used "attention getters" to a greater degree when referring to addressees of older age than when referring to addressees of the same age or younger (teenagers):

(1) Excuse me! Would you show me how to get to the bus stop? Please.

(2) Excuse me, could you help me with the directions, please?

Greetings as an initial speech formula were used much less frequently. According to the received data informants used formal greetings (Hello, Good morning, Good afternoon). The most frequently used greetings were Hello (16\%), Good morning (10\%). Most often they were used while addressing addressees of the same age or younger. When addressing older informants, greetings were used much less frequently. Informal (neutral) greetings (Hey, Hi) were used only when addressing men and women of the same age or younger and teenagers:

(3) Hey, could you show me the way to the bus stop, please.

(4) Hello! Do you know where the bus stop is?

Based on the results of our study, nominative address forms in the context of our research were used much less frequently and at the same time their usage didn't depend on the age of the addressee. The informants used them with approximately the same degree of frequency. The results of the study show that informant used nominative address forms, as an initial speech formula, only in combination with the "attention getters" or greetings.

Nowadays honorific titles can be used in extremely rare situations. In the given context honorific titles were used mainly as a polite address form and only when 
referring to the addressees of older age. Honorific titles were used to emphasize the high status of the interlocutor. For men, the speakers mostly used such honorific title as Sir and for women they usually used - Madam:

(5) Excuse me Madam, could you show me the way to the bus station, please.

(6) Excuse me Sir! Would you show me how to get to the bus stop? Please.

When addressing the interlocutor of the same social status and he same age the informants prefer not to use honorific titles. As T. Larina notes "this fact highlights the growth of informality in society and the insignificance of "status distance" which is now characteristic of the British communicative culture" [2].

While addressing informants of the same age, nominative address forms were also used. According to the received data nominative address forms were not widely used. Mostly the following address forms were used as: buddy, mate, dear, luv:

(7) Excuse me dear, could you show me the way to the bus stop, please.

(8) Hello mate, could you show me the way to the bus stop, please.

When addressing teenagers, nominative address forms were rarely used. Informants mainly used such nominative address forms as: buddy, mate and child:

(9) Hey, Buddy. Do you know where the bus stop is?

(10) Hello mate. Can you show me way to the bus stop?

The usage of informal address forms while addressing the interlocutors of the same age confirms the fact of the grown informality in the British communicative culture. The received data confirms the fact of the changing values nowadays. According to our research the informants prefer not to point out on the status and age difference among the interlocutors.

Based on the obtained results, in British culture, the use of a zero initial speech formula is characteristic, regardless of the social and gender characteristics of the addressee (age and sex), which indicates the autonomy and distance of the British communicative culture. If informants use nominative address forms, they use them only in the combination with the "attention getter" or greeting, which are used not only to attract attention, but also to establish contact with the addressee.

\section{ADDRESS FORMS IN CANADIAN ENGLISH}

According to our research Canadians don't normally use address forms in a given situation (while addressing a stranger). Normally the speakers tried to avoid the usage of address forms. The speakers prefer to address strangers with the help of the "attention getter" - Excuse me or a greeting, without nominative address forms in order to attract attention of the interlocutor. Informants used "attention getters" usually when referring to addressees of older age or of the same age. While addressing the interlocutor who was younger or even a teenager they didn't use attention getters:

(11) Excuse me! Can you please tell me how to get to...

(12) Excuse me, can you please give me directions to the bus stop?

Greetings as an initial speech formula were used with the same frequency while addressing the interlocutors of the same age or older. According to the received data informants used formal greetings (Hello, Good morning). The most frequently used 
greetings were Hello (28\%), Good morning (10\%). Most often they were used while addressing addressees of the same age or older. When addressing younger informants, greetings were used much more frequently. Informal (neutral) greetings $(\mathrm{Hi})$ were used often when addressing younger informants and teenagers:

(13) Hi, can you tell me how to get to the bus stop.

(14) Hi there, do you know where the bus stop is?

According to the results of our study, nominative address forms in the context of our research are used very seldom and at the same time their usage does not depend on the age of the addressee. The informants used them with approximately the same degree of frequency. The results of the study show that informant used the nominative address forms, as an initial speech formula, only in combination with the "attention getters" or greetings.

Presently honorific titles can be used in extremely rare situations. In the given context honorific titles were used mainly as a polite address form and only when referring to the addressees of older age. Honorific titles were used to emphasize the high status of the interlocutor. Normally Canadians used such honorific title as: Sir (for men) and Madam (for women):

(15) Excuse me Madam, can you tell me how to get to the bus stop.

(16) Excuse me Sir! Do you know how to get to the bus stop? Please.

While addressing informants of the same age or younger people nominative address forms were also used very seldom. According to the received data nominative address forms were not widely used. Mostly the following address forms were used as: buddy, mate:

(17) Hello mate, can you tell me how to get to the bus stop.

When addressing teenagers, nominative address forms were seldom used. Informants mainly used such nominative address forms as buddy:

(18) Hell, Buddy. Do you know where the bus stop is?

Canadians do not have such a strict social hierarchy, which requires incredibly formal rules, unlike the representatives of British culture. What is considered polite is "in the middle" for Canadians. It means that Canadians behave formally in some social situation or when they don't know for sure how to behave. According to the received data the informants prefer not to point out on the status and age difference among the interlocutors.

\section{DATA ANALYSES}

According to our research we have analyzed the results of the situation where the informants were required to address a stranger of different age in everyday situation:

- a man who was older;

- a man of the same age;

- a woman who was older;

- a woman of the same age;

- a teenager. 
As the aim of our study was to study symmetrical and asymmetrical relationships between the interlocutors we have found some similarities and differences in the usage of address forms.

Any communicative act begins with an initial speech formula. Based on the study, in British and Canadian communicative cultures, we can distinguish three the most frequent initial speech formulas:

- formula for attracting attention;

- greeting;

- nominative address form, which is used only in the combination with the attention getter or greeting.

According to the results of our study the British and Canadian speakers didn't normally use nominative address forms or used zero address forms as the initial speech formula. As the representatives of British style of communication ignore status it is so called person-oriented [11]. British speakers more likely than Canadian speakers used "attention getters". Greetings were more likely used by Canadian speakers, especially while addressing teenagers (See table 1).

Table 1

Attention Getters

\begin{tabular}{|l|l|c|c|}
\hline \multicolumn{1}{|c|}{ “Attention getters" } & \multicolumn{1}{|c|}{$\begin{array}{c}\text { Bddressee } \\
\text { English (\%) }\end{array}$} & $\begin{array}{c}\text { Canadian } \\
\text { English (\%) }\end{array}$ \\
\hline & Old man & 94 & 62 \\
\hline & A man of the same age & 78 & 58 \\
\hline & Old woman & 92 & 68 \\
\hline & A woman of the same age & 76 & 60 \\
\hline Total & A teenager & 68 & 10 \\
\hline Greetings & & $\mathbf{8 1 , 6}$ & $\mathbf{5 1 , 6}$ \\
\hline & & 6 & 38 \\
\hline & Old man & 22 & 42 \\
\hline & A man of the same age & 8 & 32 \\
\hline Total & Old woman & 24 & 40 \\
\hline & A woman of the same age & 32 & 90 \\
\hline & A teenager & $\mathbf{1 8 , 4}$ & $\mathbf{4 8 , 4}$ \\
\hline
\end{tabular}

The results of our study confirmed some previous observations and showed new peculiarities. The British communicative culture is characterized by a formal style of communication, which is based on the principle of maintaining distance between interlocutors.

According to the obtained data the representatives of both cultures prefer to use a zero address form as the initial speech formula. British speakers often use "attention getters" while Canadians use both "attention getters" and greetings with the same frequency. While addressing a stranger the representatives of both countries use a formal style of communication. The principle of maintaining distance between interlocutors is the basic one for British speakers. The usage of informal address forms while addressing the interlocutors of the same age confirms the fact of the grown informality in the British communicative culture. The received data confirms the fact of the changing values nowadays. As for the representatives of both cultures distance and equality in society play a fundamental role. If there is a difference in age, they prefer not to em- 
phasize this asymmetry. If the representatives of both cultures use a nominative address form, they use it only in combination with the "attention getter" or greeting, the function of which is not only to attract attention, but also to establish contact with the addressee.

\section{CONCLUSION}

In this article we have presented the results of the analysis of communicative behavior of the Canadian and British speakers relating to the usage of the initial speech formula (address form), while addressing a stranger in everyday situation. The article was devoted to sociocultural features that influence the choice of language means for expressing the initial speech formula. We have examined the usage of address forms in the boundaries of one language but in two different countries (Canada, Great Britain) with their historical and cultural background. In this article we have presented only selected results as it's not possible to list all the differences in one paper.

The results of our study confirmed some previous observations and showed some new peculiarities. While addressing a stranger the representatives of both countries use a formal style of communication, as distance and equality play a great role for the representatives of both cultures. The principle of maintaining distance between the interlocutors is the basic one for the representatives of British culture. Nowadays, as the result of the development of our modern world along the way of cooperation in all spheres of human life and mutual influence of different cultures, there are some changes in the communicative behavior. The usage of informal address forms while addressing the interlocutors of the same age confirms the fact of the grown informality in the British communicative culture. The received data confirms the fact of the changing values nowadays.

(С Юрьева Ю.Б., 2018

Дата поступления: 10.11.2018

Дата приема в печать: 03.03.2019

\section{REFERENCES}

1. Larina, T. (2015). Culture-Specific Communicative Styles as a Framework for Interpreting Linguistic and Cultural Idiosyncrasies. International Review of Pragmatics, 7 (5). Special Issue: Communicative Styles and Genres, 195-215.

2. Larina, T. \& Suryanarayan, N. (2013). Madam or aunty ji: address forms in the British and Indian languages. In Monika Reif, Justina A. Robinson, Martin Putz (eds.). Variation in Language and Language Use: Linguistic, Socio-Cultural and Cognitive Perspectives. Peter Lang Edition. pp. 190-217.

3. Hofstede, G.H. (1991). Cultures and Organizations: Software of the mind. McGraw-Hill Book Company (UK) Limited. London.

4. Kecskes, I. (2014). Intercultural pragmatics. OUP USA.

5. Brown, P. \& Levinson, S. (1987). Politeness: Some Universals in Language Usage. Cambridge: CUP.

6. Leech, G. (2014). The pragmatics of politeness. Oxford: Oxford University Press.

7. Fitch, K. (1998). Speaking Relationally: Culture, Communication, and Interpersonal Connection. New York: The Guilford Press.

8. Clyne, M., Norrby, C. \& Warren, J. (2009). Language and Human Relations: Style of Address in Contemporary Language. Cambridge: CUP. 
9. Kachru, B. (2012). World Englishes: Agony and Ecstasy. Journal of Aesthetic Education, 30 (2), Special Issue: Distinguished Humanities, 135-155.

10. Wierzbicka, A. (2003). Cross-cultural pragmatics: The Semantics of Human Interaction. Berlin, New York: Mouton de Gruyter.

11. Gudykunst, W. \& Ting-Toomey, S. (1990). Culture and Interpersonal communication. Interpersonal communication, 8. Sage Series. Sage Publications.

12. Giles, H. (1977). Language, Ethnicity and Intergroup Relations: European Monographs in Social Psychology. London: Academic Press.

13. Gladkova, Anna \& Larina, Tatiana (2018). Anna Wierzbicka, Language, Culture and Communication. Russian Journal of Linguistics, 22 (4), 717-748. doi: 10.22363/2312-9182-2018-224-717-748.

14. Iliadi, P.L. \& Larina, T.A. (2017) Refusal Strategies in English and Russian. RUDN Journal of Language Studies, Semiotics and Semantics, 8 (3), 531-542. doi: 10.22363/2313-2299-20178-3-531-542.

15. Hall, E. (1990). Understanding Cultural Differences: Germans, French and Americans. Yarmouth, Maine: Intercultural Press.

16. Clyne, M. (2009). Address in intercultural communication across languages. Intercultural Pragmatics, 6 (3), 395- 409.

17. Crystal, D. (2013). English as a Global Language. Cambridge: Cambridge University Press.

18. Schneider, K.P. (2010) Sociopragmatic variation and culture-dependent schemata of linguistic behavior. In 34th International LAUD Symposium. Cognitive Sociolinguistics: Language Variation in its Structural, Conceptual and Cultural Dimensions. Landau / Pfalz (Germany). pp. $245-275$.

\title{
ФОРМА ОБРАЩЕНИЯ КАК ОТРАЖЕНИЕ ЭТНОКУЛЬТУРНОГО СТИЛЯ КОММУНИКАЦИИ (на материале британского и канадского вариантов английского языка)
}

\author{
Ю.Б. Юрьева \\ Российский университет дружбы народов \\ Ул. Миклухо-Маклая, 6, Москва, Россия, 117198
}

Культура и процесс коммуникации неразделимы, так как культура не только указывает, между какими членами общества возможен процесс коммуникации, но и помогает правильно распознать значение сообщения, которое было закодировано, а также при каких условиях данное сообщение будет правильно интерпретировано собеседником.

Сложившийся исторически, этнокультурный стиль коммуникации (Т.В. Ларина) отражает коммуникативные особенности поведения народа при выборе вербальных и невербальных средств в процессе коммуникации.

Статья посвящена социокультурным особенностям, которые влияют на выбор языковых средств при выражении инициальной речевой формулы. Целью нашего исследования было изучение форм обращения в рамках одного языка, но в двух разных странах (Канада, Великобритания) с их историческим и культурным прошлым. Мы основываемся на параметрах измерения культур Г. Хофштеда (1991), теории вежливости (Браун \& Левинсон 1987, Лич 2014), основах межкультурной 
прагматики (А. Вежбицкая 2003, И. Кечкеш 2014), теории речевой аккомодации (Х. Гайлс). В статье представлены результаты исследования употребления форм обращения среди представителей британской и канадской культур с целью выявления сходств и различий и объяснение результатов через особенности культур.

Ключевые слова: инициальная речевая формула, форма обращения, канадский вариант английского языка, британский вариант английского языка, межкультурная коммуникация

\section{БИБЛИОГРАФИЧЕСКИЙ СПИСОК}

1. Larina T. Culture-Specific Communicative Styles as a Framework for Interpreting Linguistic and Cultural Idiosyncrasies // International Review of Pragmatics. Vol. 7. No 5. Special Issue: Communicative Styles and Genres. 2015. P. 195-215.

2. Larina T., Suryanarayan N. Madam or aunty ji: address forms in the British and Indian languages. // Variation in Language and Language Use: Linguistic, Socio-Cultural and Cognitive Perspectives / Monika Reif, Justina A. Robinson, Martin Putz (eds.). Peter Lang Edition, 2013. P. $190-217$.

3. Hofstede G.H. Cultures and Organizations: Software of the mind. McGraw-Hill Book Company (UK) Limited. London, 1991.

4. Kecskes I. Intercultural pragmatics, OUP USA, 2014.

5. Brown P., Levinson S. Politeness: Some Universals in Language Usage. Cambridge: CUP, 1987.

6. Leech $G$. The pragmatics of politeness. Oxford: Oxford University Press, 2014.

7. Fitch K. Speaking Relationally: Culture, Communication, and Interpersonal Connection. New York: The Guilford Press, 1998.

8. Clyne M., Norrby C., Warren J. Language and Human Relations: Style of Address in Contemporary Language. Cambridge: CUP, 2009.

9. Kachru B. World Englishes: Agony and Ecstasy // Journal of Aesthetic Education. 2012. No 30 (2). Special Issue: Distinguished Humanities. P. 135-155.

10. Wierzbicka A. Cross-cultural pragmatics: The Semantics of Human Interaction. 2nd edition. Berlin, New York: Mouton de Gruyter, 2003.

11. Gudykunst W., Ting-Toomey S. Culture and Interpersonal communication// Interpersonal communication. 8. Sage Series. Sage Publications, 1990.

12. Giles H. Language, Ethnicity and Intergroup Relations: European Monographs in Social Psychology. London: Academic Press 1977.

13. Гладкова А.Н., Ларина Т.В. Анна Вежбицкая: язык, культура и коммуникация // Вестник Российского университета дружбы народов. Серия: Лингвистика = Russian Journal of Linguistics. 2018. No 22 (4). C. 717-748. doi: 10.22363/2312-9182-2018-22-4-717-748.

14. Илиади П.Л., Ларина Т.В. Стратегии отказа в английской и русской лингвокультурах // Вестник Российского университета дружбы народов Серия: Теория языка. Семиотика. Семантика, 2017. № 8 (3). С. 531-542. doi: 10.22363/2313-2299-2017-8-3-531-542.

15. Hall E. Understanding Cultural Differences: Germans, French and Americans. Yarmouth, Maine: Intercultural Press, 1990.

16. Clyne M. Address in intercultural communication across languages // Intercultural Pragmatics. 2009. No 6 (3). P. 395- 409.

17. Crystal D. English as a Global Language. Cambridge: Cambridge University Press, 2013.

18. Schneider K.P. Sociopragmatic variation and culture-dependent schemata of linguistic behavior // 34th International LAUD Symposium. Cognitive Sociolinguistics: Language Variation in its Structural, Conceptual and Cultural Dimensions. Landau / Pfalz (Germany), 2010. P. 245-275.

\section{For citation:}

Yuryeva, Yu.B. (2019). Address form as a reflection of ethno-cultural style of communication (based on British and Canadian English). RUDN Journal of Language Studies, Semiotics and Semantics, 10 (2), 532-543. doi: 10.22363/2313-2299-2019-10-2-532-543. 


\section{Для цитирования:}

Юрьева Ю.Б. Форма обращения как отражение этнокультурного стиля коммуникации (на материале британского и канадского вариантов английского языка) // Вестник Российского университета дружбы народов. Серия: Теория языка. Семиотика. Семантика. Т. 10. № 2. C. 532-543. doi: 10.22363/2313-2299-2019-10-2-532-543.

\section{Information about the author:}

Yulia B. Yuryeva, PhD student of the Department of Foreign Languages, RUDN University; Research interests: comparative linguistics, pragmatics, discourse analysis, methods of teaching foreign languages; e-mail: yuryeva-yub@rudn.ru

\section{Сведения об авторе:}

Юрьева Ю.Б., аспирант кафедры иностранных языков филологического факультета РУДН; научные интересы: сравнительно-сопоставительное языкознание, прагматика, дискурсивный анализ, методика преподавания иностранных языков; e-mail: yuryeva-yub@rudn.ru 